\title{
Investigatingthe Effects of Employee Empowerment on Job Satisfaction and Performance: A Case Study of Front Office Employees in EgyptianHotels
}

\author{
Yasser Ibrahim, Tamer M. Abbas and Mostafa N. Marghany \\ Faculty of Tourism and Hotel Management, Helwan University, Egypt
}

\begin{abstract}
:
Several elements could affect human performance in hospitality organizations; one of these elements is empowerment.Empowerment is the process of enabling employees in many forms and ways including delegating, training and development, job rotation, and fair promotion opportunities. Hospitality organizationsneed to empower their employees to go extra miles to meet customer expectations.Using data gathered fromfront office employees in three-star and five-star hotels, this study investigated the effects of employee empowerment on employee job satisfaction and employee performance. The study employed a selfadministered questionnaire consisted of 29 items. The items divided into five groups as job involvement (JI), organizational commitment (OC), psychological empowerment (PE), job satisfaction (JS), and job performance (JP). Confirmatory factor analysis (CFA)and Structural equation modeling (SEM) were conducted to test a hypothesizedmodel. Findings revealed thatempowerment through involvement, empowerment through commitment and psychological empowerment significantly impact employee job satisfaction, in the five-star hotels. However, onlyempowerment through commitment and psychological empowerment significantly impact employee job satisfaction, in the three-star hotels. Moreover, results showed that employee job satisfaction has positive effects on employee performance, in both the three-star and five-star hotels.
\end{abstract}

Keywords: employee empowerment, job involvement, organizational commitment, psychological empowerment, job satisfaction,employee job performance. 


\section{INTRODUCTION}

Many hotels such as Marriott have embraced the concept of employeeempowerment as a human resource management strategy that is critical fordefining their service and as a core competitive advantage (He et al., 2010). These hotels are encouraged to consider employee performance, as a means to gain competitive advantage (Karatepe and Kilic, 2007). Subsequently, many scholars (e.g., Logan and Ganster, 2007;Davidson et al., 2010) have investigated workplace issues that may have impact on employee performance, in order to develop strategies to improve both individual and organizational performance. One of these issues includes the tacit acceptance that employee empowerment is quite appropriate and an accepted element of life within the industry (Davidson et al., 2010). Empowerment is defined as "encouraging people to become more involved in the decisions and activities that affect their jobs and providing them with the opportunity to show that they can come up with good ideas and that they have the skills to put these ideas into practice" (Smith 1996, p. 9).

The concept of employee empowerment has been emphasized as a key to closing the emergent power gaps, to reduce the growing powerlessness in workplace settings and thereby stimulates the performance of employees. Incidentally, the lack of empowerment of employees has particularly been cited as a problematic issue in successful partnering and other collaborative practices been advocated ( $\mathrm{Ng}$ et al., 2002). It is argued that empowered employees produce better service and are more satisfied with their jobs (Boudrias et al., 2009). Most of the existing empowerment studies have been conducted in the service industry(Honold, 1997). And most of these studies have been conducted in developed countries. There is a lack of research on employee empowerment in the hospitality industry in developing countries (Logan and Ganster, 2007;Ayupp and Chung, 2010; Raub and Robert, 2012). Therefore, this study attempts to add to that literature by examining the effects ofemployee empowerment on employee job satisfaction and employee performance using datacollected from front-office employees in three-star and five-star hotels in Egypt. 


\section{LITERATURE REVIEW \\ Empowerment}

Empowerment can be defined as a collection of practices that combine information sharing, delegation of authority, and increased employee autonomy with an increased reliance on teams or as method of delegation which enables work decisions to be taken as near as possible to the operating units and their customers.(Ayupp and Chung, 2010; Raub and Robert, 2012).Various researchers have considered the dimensions of empowerment through different perspectives such as involvement, participation, decision-making authority, and delegation. Wilkinson (1998) stated that the empowerment term is generally used to refer to a form of employee involvement initiative and participation.From the decision-making perspective, empowerment is defined as "a philosophy of giving more responsibility and decision-making authority to more junior people in the organization (Shackleton, 1995, p.130). From the delegation perspective, Seibert et al. (2004) considered empowerment as increasing individual motivation at work through the delegation of authority to the lowest level in an organization where a competent decision can be made.

In the hospitality establishments,empowerment is used to describe several practices. For instance, in the Hilton hotels, empowerment has been used to describe employee involvement in developing departmental service standards. In McDonald's restaurants, empowerment has been used to describe suggestion schemes. In Harvester restaurants, empowerment has been used to describe independent work groups and removal of levels of management (Ayupp and Chung, 2010).Generally, the idea of empowerment depends on a high degree of flexibility and acting freely to make decisions in the workplaces. Most definitions of empowerment focused on giving employees more authority, freedom, and discretion in some tasks which related to the one's work.

The notion of empowerment has come from creating a competitive environment in organizations in order to increase efficiency(Leach et al., 2003), service quality (Melhem, 2004; Spreitzer, 2007; He et al., 2010), employee satisfaction (Gazzoli et al., 2010; He et al., 2010), leadership 
(Arnold et al., 2000), profitability (Raub and Robert, 2012), productivity and innovation(Boudrias et al., 2009), and organizational effectiveness (Logan and Ganster, 2007). Employee empowerment became a managerial interest in the various hospitality establishments to gain a competitive advantage through improvements in service quality. In today's competitive environment, hospitality organizations need toallocate more authority to their frontline employees, who face a greateruncertainty from increasingly demanding consumers. Empowered frontlineemployees can respond promptly to the individual customer's needs and dowhatever it takes to delight the customer (Lashley,2001).

Frontline employees' empowerment is necessary because they are considered as the direct contact for guests and as such need to have freedom to act with guests' concerns effectively. Using empowerment can boost employees' self-efficacy to decide the best way to carry out a given task. Empowerment helps employees to be more knowledgeable and adaptive (Ayupp and Chung, 2010). In addition, employee empowerment in frontline is a central theme of many industrial and academic comments about service quality.

\section{Forms of Empowerment}

Different forms of empowerment were applied in practice in hospitality establishments such as empowerment through involvement, empowerment through commitment, and psychological empowerment (Lashely, 1995, 1999, and 2001).

Empowerment through involvement is the first form of empowerment. O'Creevy (2001) suggested that such employee involvement practices are simply a means by which employers can defuse attempts to provide workers with any real control. Employers introduce involvement as a way of appearing to share some degree of control in the face of threats to their authority from workers' organizations. Furthermore, he defined Employee involvement as the exercise, by employees, of influence over how their work is organized and carried out. Zopiatis et al. (2014) hypothesized that job involvement provides the opportunity for individuals to make decisions, the foundation for strengthening their job involvement. In the hospitality establishments, $\operatorname{Lashely}(2001)$ organized some ways to 
empower employees via involvement. For instance, the quality circles that focused on increasing employee involvement and gaining improvements in service quality, indeed, this way was applied in Accor Group. Second, team briefings in Hilton Hotels and TGI Fridays provided a mechanism for managers and employees to meet on a regular basis to discuss operational issues. Finally, suggestion schemes in McDonald's. All these ways are attempts to include the ideas and experiences of employees in managerial decision-making processes.

Empowerment through commitment is the second form of empowerment. Chiang and Jang (2008) indicated that organizational commitment refers to an individual's attachment to, loyalty to, and identification with the organization. Steers (1977) defined organizational commitment as "the relative strength of an individual's identification with and involvement in a particular organization" (p.46). Robbins and Judge (2007) determined three dimensions of organizational commitment, they proceeded to define each dimension beginning with affective commitment as "the degree to which an employee identifies with a particular organization and its goals and wishes to maintain membership in the organization" (p.81). For example, employees remain at their current workplace because they want to. The second is continuance commitment defined as "the perceived economic value of remaining with an organization compared to leaving it" (p.81). For instance, they remain because they need to, while the last dimension is normative commitment, it described as "an obligation to remain with the organization for moral or ethical reasons" (p.81). For example, employees feel as though they should remain in the organization because they "owe it" to their current employer.

Psychological empowermentis the third form of empowerment and it includes participative decision making that considered one of the most effective dimensions of psychological empowerment.Psychological climate reflects a judgment by the employees about the degree to which the work environment is beneficial to their sense of well-being (Carless, 2004). Spreitzer et al. (1997) described psychological empowerment as a group of psychological states essential for a person to feel that he or she can control the relationship to his or her own work. Thomas and Velthouse (1990, p.672) identified four psychological dimensions of empowerment: impact, competence, meaningfulness, and choice.Impact 
is "the degree to which behavior is seen as making a difference in terms of accomplishing the purpose of the task". Competence is "the degree to which a person can perform task activities skillfully when he or she tries". Meaningfulness involves "the individual's intrinsic caring about a given task".Choice/self-determination involves "causal responsibility for a person's actions".

\section{Hypotheses}

In hospitality establishments, frontline employees have direct interaction with customers. Customer perception, satisfaction and loyalty are developed during such interactions. Frontline employees should be satisfied in order to deliver quality service and satisfaction to customers (Spinelli and Canavos, 2000). Efraty and Sirgy (1990) described job satisfaction as "one's effective appraisal of various job dimensions". Salaries, wages, relationship with coworkers and supervisors, promotion policies, empowerment and work itself are important indicators of job satisfaction (Gallardo et al. 2010; Lee and Way, 2010). In particular, previous researches (e.g., Joo and Park, 2009) showed positive relationships between the different forms of empowerment and employee jobsatisfaction. Employees felt satisfied if they were involved in decision making processes, gained appropriate job training and employee benefits, and had an effective manager (Spinelli and Canavos, 2000). Therefore, this study hypothesizes that:

Hypothesis 1: Job involvement positively impacts employee job satisfaction.

Hypothesis2: Organizational commitment positively impacts employee job satisfaction.

Hypothesis 3:Psychological empowerment positively impacts employee job satisfaction.

Moving to employee performance, a positive causal relationship between employee job satisfaction and performance has been found (Kelly, 1992; Sigler and Pearson, 2000). Employees who have the skills necessary to do their jobs and the freedom to choose how to complete their tasks should 
have higher levels of performance. Moreover, employees who feel their job has meaning and have perceptions of competence and perceptions of influence have also shown indications of higher performance levels (Sigler and Pearson, 2000). Hence, this study hypothesizes that:

Hypothesis 4: Employee job satisfaction positively impacts employee performance.

Besides, employee gender, age, experience, and hotel category might affect employee performance. In particular, previous researches (e.g., Tuuli and Rowlinson, 2009; Awamleh, 2013) showed that male, younger, and experienced employees showed better performance than their counterparts. Moreover, employees in luxury hotels showed better performance than employees in budget hotels (Rathore and Rathore, 2015).Therefore, this study hypothesizes that:

Hypothesis 5:Male employees show higher levels of performance than female employees.

Hypothesis 6:Younger employees show higher levels of performance than elder employees.

Hypothesis 7:More experienced employees showhigher levels of performance than less experienced employees.

Hypothesis 8:Employees working in five-star hotels show higher levels of performance than employees working in threestar hotels.

The given hypotheses are expressed in the the proposed research modelshown inFigure 1. 


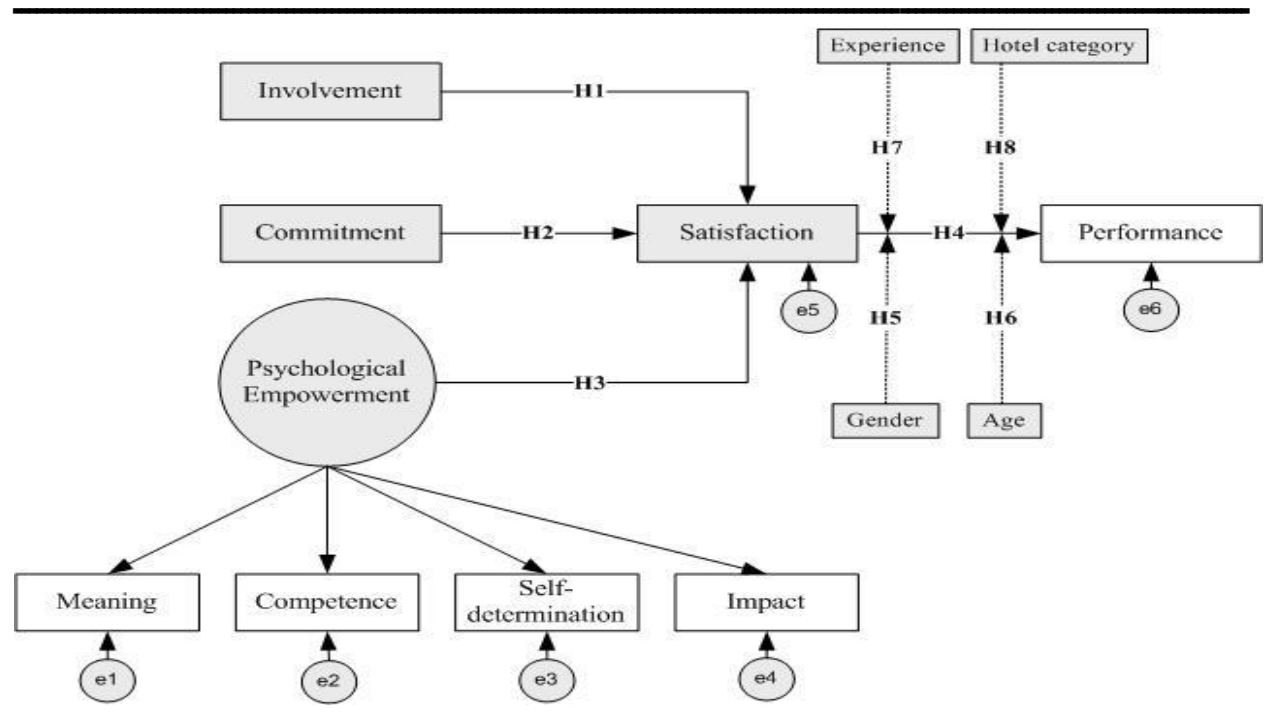

Figure 1: The proposed research model

\section{METHODOLOGY}

To test the hypotheses against the proposed model, a survey was conducted. Data were collected via a self-administrated questionnaire.The target population for this study was all front-office employees in threestar and five-star hotels in Greater Cairo. A convenience sample of fifteen three-star hotels out of forty hotels and nine five-star hotels out of thirtythree hotels was selected for this study (Egyptian Hotel Association, 2013). A number of 266 questionnaires were distributed to a convenience sample of front-office employees. A total of 184 questionnaires were completed and valid for analysis, thus achieving a response rate of $69.17 \%$.

\section{Survey Instrument}

To measure the constructs in the proposed model,a questionnaire was adapted from validated from previous research studies. The final questionnaire items are listed in Table 1 along with their sources. The questionnaire is divided into two sections. In the first section, employees were asked to rate 29 items on a five-point Likert type scale ranging from strongly disagree (1) to strongly agree (5). The 29 items are divided into five variables: job involvement (5 items), organizational commitment (3 
items), psychological empowerment (12 items), job satisfaction (3 items), and job performance (6 items). The second section asked employees for profiling information (e.g., gender, age, and years of experience). 
Investigatingthe Effects of Employee Empowerment on Job Satisfaction and Performance: A Case Study of Front Office Employees in Egyptian Hotels

Table 1: Construct measurement and sources

\begin{tabular}{|c|c|c|c|c|c|c|c|}
\hline \multirow[b]{2}{*}{ Construct } & \multirow[b]{2}{*}{ Source } & \multirow{2}{*}{$\begin{array}{c}\text { Item's } \\
\text { label }\end{array}$} & \multirow[b]{2}{*}{ Items } & \multicolumn{2}{|c|}{ 3-star hotels } & \multicolumn{2}{|c|}{ 5-star hotels } \\
\hline & & & & Mean & $\begin{array}{r}\text { Std } \\
\text { dev. }\end{array}$ & Mean & $\begin{array}{l}\text { Std } \\
\text { dev. }\end{array}$ \\
\hline Job & Zopiatis et & JI1 & I like to be absorbed in my job most of the time. & 3.45 & .893 & 3.60 & 1.068 \\
\hline \multirow[t]{4}{*}{ Involvement } & al. $(2014)$ & $\mathrm{JI} 2$ & I consider my job to be very important to my existence. & 4.09 & .734 & 3.91 & 1.187 \\
\hline & & $\mathrm{JI} 3$ & Most of my personal life goals are job oriented. & 3.52 & 1.14 & 3.73 & 1.136 \\
\hline & & $\mathrm{JI} 4$ & Most of interests are centred on my job. & 3.00 & .976 & 3.56 & 1.071 \\
\hline & & JI5 & Overall, I am very much personally involved in my job. & 3.19 & 1.10 & 3.73 & 1.114 \\
\hline Organizational & Chiang & OC1 & I feel myself to be part of this hotel. & 3.53 & 1.10 & 3.76 & 1.196 \\
\hline \multirow[t]{2}{*}{ Commitment } & and Jang & $\mathrm{OC} 2$ & I am willing to achieve this hotel's goals and values. & 4.09 & 1.01 & 3.91 & 1.070 \\
\hline & $(2008)$ & $\mathrm{OC} 3$ & Overall, I am willing to continue work at this hotel. & 3.73 & 1.09 & 3.73 & 1.189 \\
\hline Psychological & Spreitzer & PE1 & The work I do is very important to me. & 4.00 & 1.17 & 4.00 & .948 \\
\hline \multirow[t]{11}{*}{ Empowerment } & $(1995)$ & PE2 & My job activities are personally meaningful to me. & 4.13 & 1.02 & 3.97 & .940 \\
\hline & & PE3 & The work I do is meaningful to me. & 4.12 & .981 & 4.02 & .969 \\
\hline & & PE4 & I am confident about my ability to do my job. & 4.47 & .717 & 4.13 & .986 \\
\hline & & PE5 & I am self-assured about my capabilities to perform my & 4.53 & .733 & 4.11 & 1.019 \\
\hline & & PE6 & I have mastered the skills necessary for my job. & 4.44 & .715 & 4.04 & 1.059 \\
\hline & & PE7 & I have significant autonomy in determining how I do my job. & 3.78 & .822 & 3.54 & 1.150 \\
\hline & & PE8 & I can decide on my own how to go about doing my work. & 3.13 & .686 & 3.49 & 1.212 \\
\hline & & PE9 & I have opportunity for independence in how I do my job. & 3.89 & .887 & 3.48 & 1.224 \\
\hline & & PE10 & My impact on what happens in my department is large. & 3.98 & .831 & 3.78 & 1.011 \\
\hline & & PE11 & I have a great deal of control over what happens in my & 3.87 & .961 & 3.85 & 1.034 \\
\hline & & PE12 & I have significant influence over what happens in my department. & 3.88 & .944 & 3.74 & 1.184 \\
\hline Job & Chiang & JS1 & I am satisfied with my job. & 3.60 & 1.29 & 3.89 & 1.120 \\
\hline \multirow[t]{2}{*}{ Satisfaction } & and Jang & JS2 & I am satisfied with the empowerment of my job. & 3.71 & .872 & 3.77 & 1.177 \\
\hline & $(2008)$ & JS3 & Overall, I am happy for working at this hotel. & 3.50 & 1.17 & 3.90 & .979 \\
\hline Job & Tuuli and & $\mathrm{JP} 1$ & I adequately complete assigned duties. & 4.00 & .744 & 4.04 & .941 \\
\hline \multirow[t]{5}{*}{ Performance } & Rowlinson & JP2 & I fulfill responsibilities specified in my job description. & 4.01 & .720 & 4.04 & 1.039 \\
\hline & & JP3 & I perform tasks that are expected of me. & 3.94 & .766 & 4.06 & .982 \\
\hline & & JP4 & I meet the formal performance requirements of my job. & 3.85 & .720 & 4.01 & 1.015 \\
\hline & & JP5 & I do things that will directly affect my performance appraisal. & 4.40 & .730 & 3.71 & 1.175 \\
\hline & & JP6 & I neglect aspects of the job I am obliged to perform. & 3.15 & 1.16 & 2.41 & 1.384 \\
\hline
\end{tabular}




\section{Data Analysis}

AMOS version 20 was used for data analysis.A two-step approach for structural equation modeling (SEM) was used. In the first step, confirmatory factor analysis (CFA) was used to test the measurement models. In the second step, maximum likelihood was used to estimate the structural models and to explore the causal relationship among all variables. Composite reliability (CR) and Cronbach's $\alpha$ for each latent variable were used to test the construct reliability, and average variance extracted (AVE) was used to test the construct convergent and discriminant validity (Hair et al., 2010). Furthermore, the Mann-Whitney U test was used in this study to compare the scores of employees' gender in three-star and five-star hotels, and to compare the scores of the two hotel categories. The Kruskal-Wallis test was also used in this study.

\section{RESULTS}

\section{Profile of the Sample}

Table 2 presents the profile of the sample of front-office employees in the investigated hotels. Particularly, 85 employees were selected from three-star hotels, while 99 employees were selected from five-star hotels. While the employees comprised of $89.4 \%$ females and $10.6 \%$ males in three-star hotel, they comprised $69.7 \%$ females and $30.3 \%$ males in five-star hotels. Most of the employees of the three-star $(55.3 \%)$ and five-star $(63.6 \%)$ hotels aged less than 30 years old. The majority of employees of the three-star $(87.1 \%)$ and five-star $(81.1 \%)$ hotels had a university degree. With regards to experience in the hotel industry, almost half of the three-star hotel employees (49.4\%)had experience from 5 to 10 years. While, almost half of the employees of the five-star hotels $(54.5 \%)$ had work experience less than 5 years. The majority of the employees of the three-star (70.6\%) and five-star $(68.7 \%)$ hotels had work experience in the current hotel less than 5 years. The majority of the investigated three-star hotels (94\%) were less than 100 rooms. However, most of the five-star hotels $(64.6 \%)$ were higher than 400 rooms. Regarding the management type, all the three-star hotels were managed independently, while, approximately (90 $\%)$ of five-star hotels were international chains, and (10\%) of them were managed independently. 


\section{Investigatingthe Effects of Employee Empowerment on Job Satisfaction and \\ Performance: A Case Study of Front Office Employees in Egyptian Hotels}

\section{Structural Equation Modeling}

\section{Confirmatory factor analysis (CFA)}

In the current study, confirmatory factor analysis (CFA) was used to test the scales reliability of the data collected from the front-office employees in the three-star and five-star hotels. To ensure a good reliability level, only scales with composite reliability and Cronbach's $\alpha$ over the value of 0.7 were remained (Hair et al., 2010). Accordingly, self-determination measure of the psychological empowerment was removed $(\alpha<0.7)$. On the other hand, to ensure good convergent validity, all values of average variance extracted (AVE) of scales should exceed the value of 0.5 (Hair et al., 2010) as shown in Table 3. Furthermore, to ensure good discriminant validity, the AVE value of each scale should be greater than the squared correlation for each pair of scales (Hair et al., 2010) as shown in Table 4.

In addition, CFA was used to measure the structure fit of the hypothesized model for three-star and five-star hotels (i.e., Figure 1). In this regards, some goodness-of-fit measures were utilized to assess the structural fit. Previous researchers (e.g., Bentler and Bonett, 1980) suggested that model fit should be acceptable if the chi-square $\left(\chi^{2}\right)$ is not significant. However, this rule is very sensitive to the sample size (Arbuckle, 2011). In this research, both $\left(\chi^{2}\right)$ values of the three-star and five-star hotels were significant. In particular, the three-star hotels model yielded a $\left(\chi^{2}\right)$ value of 46.471 with 18 degrees of freedom $(\mathrm{p}=0.000)$. As well, the five-star hotels model yielded a $\left(x^{2}\right)$ value of 41.133 with 18 degrees of freedom $(p=0.000)$. In order to overcome the sample size limitation, other researchers (e.g., Tabachnick and Fidell, 2007; Arbuckle, 2011) suggested that the ratio of the $\chi^{2}$ statistic to the degrees of freedom should be less than 3. In this research, this rule has been attained. In particular, the ratios of the three-star and five-star hotels models were 46.471/18 $=2.58$ and $41.133 / 18=2.26$, respectively indicating an acceptable model fit. Finally, t-values of the scale items were all statistically significant at the 0.01 percent level. 
Table 2: Profile of respondents (N=184)

\begin{tabular}{|c|c|c|c|c|}
\hline \multirow{2}{*}{ Variables } & \multicolumn{2}{|c|}{ Three-star hotels $(\mathrm{N}=85)$} & \multicolumn{2}{|c|}{ Five-star hotels $(\mathrm{N}=99)$} \\
\hline & Frequency & percentage & Frequency & percentage \\
\hline \multicolumn{5}{|l|}{ Gender } \\
\hline Female & 76 & 89.4 & 69 & 69.7 \\
\hline Male & 9 & 10.6 & 30 & 30.3 \\
\hline \multicolumn{5}{|l|}{ Age } \\
\hline Less than 30 & 47 & 55.3 & 63 & 63.6 \\
\hline 30 up to 40 & 35 & 41.2 & 24 & 24.3 \\
\hline 40 up to 50 & 1 & 1.2 & 11 & 11.1 \\
\hline 50 or older & 2 & 2.3 & 1 & 1.0 \\
\hline \multicolumn{5}{|l|}{ Education } \\
\hline Secondary school & 4 & 4.7 & 6 & 6.1 \\
\hline University degree & 74 & 87.1 & 81 & 81.8 \\
\hline Postgraduate (MBA, MSc, $\mathrm{PhD}$ ) & 7 & 8.2 & 12 & 12.1 \\
\hline \multicolumn{5}{|l|}{ Experience in hotel industry } \\
\hline Less than 5 years & 40 & 47.1 & 54 & 54.5 \\
\hline 5 up to 10 years & 42 & 49.4 & 34 & 34.3 \\
\hline 10 up to 15 years & 1 & 1.2 & 3 & 3.1 \\
\hline 15 or more & 2 & 2.3 & 8 & 8.1 \\
\hline \multicolumn{5}{|l|}{ Experience in current hotel } \\
\hline Less than 5 years & 60 & 70.6 & 68 & 68.7 \\
\hline 5 up to 10 years & 22 & 25.9 & 23 & 23.2 \\
\hline 10 up to 15 years & 2 & 2.3 & 1 & 1.0 \\
\hline 15 or more & 1 & 1.2 & 7 & 7.1 \\
\hline \multicolumn{5}{|l|}{ Respondents' hotel size } \\
\hline Less than 100 rooms & 80 & 94.1 & 0 & 0 \\
\hline 101 to 200 rooms & 5 & 5.9 & 11 & 11.1 \\
\hline 201 to 300 rooms & 0 & 0 & 0 & 0 \\
\hline 301 to 400 rooms & 0 & 0 & 24 & 24.3 \\
\hline 401 to 500 rooms & 0 & 0 & 31 & 31.3 \\
\hline More than 500 rooms & 0 & 0 & 33 & 33.3 \\
\hline \multicolumn{5}{|l|}{ Respondents' management type } \\
\hline Independent Property & 85 & 100 & 10 & 10 \\
\hline Local chain management & 0 & 0 & 0 & 0 \\
\hline International chain & 0 & 0 & 89 & 90 \\
\hline
\end{tabular}


Table 3: Factor loadings, validity analysis, and reliability test of the measurement models

\begin{tabular}{|c|c|c|c|c|c|c|c|c|}
\hline \multirow[b]{2}{*}{ Latent/Measured variables } & \multicolumn{4}{|c|}{ Three-star hotels } & \multicolumn{4}{|c|}{ Five-star hotels } \\
\hline & $\begin{array}{l}\text { Factor } \\
\text { loading }\end{array}$ & CR & AVE & $\alpha$ & $\begin{array}{l}\text { Factor } \\
\text { loading }\end{array}$ & $\mathrm{CR}$ & AVE & $\mathbf{A}$ \\
\hline Job Involvement & & 0.88 & 0.61 & 0.87 & & 0.90 & 0.64 & 0.89 \\
\hline JI1 & 1.00 & & & & 1.00 & & & \\
\hline JI2 & 0.89 & & & & 1.03 & & & \\
\hline JI3 & 1.01 & & & & 1.05 & & & \\
\hline $\mathrm{JI} 4$ & 0.96 & & & & 1.00 & & & \\
\hline JI5 & 0.94 & & & & 1.04 & & & \\
\hline Organizational Commitment & & 0.87 & 0.70 & 0.86 & & 0.89 & 0.74 & 0.88 \\
\hline OC1 & 1.00 & & & & 1.00 & & & \\
\hline $\mathrm{OC} 2$ & 0.97 & & & & 0.94 & & & \\
\hline OC3 & 0.91 & & & & 0.99 & & & \\
\hline Psychological Empowerment & & 0.94 & 0.82 & 0.94 & & 0.98 & 0.85 & 0.97 \\
\hline PE1 & 1.00 & & & & 1.00 & & & \\
\hline PE2 & 0.92 & & & & 0.99 & & & \\
\hline PE3 & 0.88 & & & & 1.03 & & & \\
\hline PE4 & 1.00 & & & & 1.00 & & & \\
\hline PE5 & 0.94 & & & & 1.04 & & & \\
\hline PE6 & 0.98 & & & & 1.03 & & & \\
\hline PE7 & 1.00 & & & & 1.00 & & & \\
\hline PE8 & 0.98 & & & & 0.97 & & & \\
\hline PE9 & 1.01 & & & & 1.08 & & & \\
\hline Job Satisfaction & & 0.85 & 0.66 & 0.84 & & 0.87 & 0.70 & 0.86 \\
\hline JS1 & 1.00 & & & & 1.00 & & & \\
\hline JS2 & 0.93 & & & & 1.06 & & & \\
\hline JS3 & 0.89 & & & & 0.87 & & & \\
\hline Job Performance & & 0.93 & 0.86 & 0.92 & & 0.96 & 0.87 & 0.95 \\
\hline JP1 & 1.00 & & & & 1.00 & & & \\
\hline JP2 & 1.02 & & & & 1.07 & & & \\
\hline JP3 & 0.96 & & & & 1.01 & & & \\
\hline JP4 & 0.94 & & & & 1.02 & & & \\
\hline
\end{tabular}

Note: All factor loadings were significant at $\leq .001 ; \mathrm{CR}=$ Composite reliability; $\alpha=$ Alpha reliability 
Table 4: Discriminant validity of themeasurement models of the three-star and five-star hotels

\begin{tabular}{lcccccccccc}
\hline \multirow{2}{*}{ Construct } & \multicolumn{4}{c}{ Three-star hotels } & \multicolumn{5}{c}{ Five-star hotels } \\
\cline { 2 - 11 } & JI & OC & PE & JS & JP & JI & OC & PE & JS & JP \\
\hline JI & $\mathbf{0 . 6 1}$ & & & & & $\mathbf{0 . 6 4}$ & & & & \\
OC & 0.44 & $\mathbf{0 . 7 0}$ & & & & 0.40 & $\mathbf{0 . 7 4}$ & & & \\
PE & 0.14 & 0.38 & $\mathbf{0 . 8 2}$ & & & 0.24 & 0.62 & $\mathbf{0 . 8 5}$ & & \\
JS & 0.32 & 0.24 & 0.49 & $\mathbf{0 . 6 6}$ & & 0.24 & 0.38 & 0.40 & $\mathbf{0 . 7 0}$ & \\
JP & 0.12 & 0.35 & 0.51 & 0.12 & $\mathbf{0 . 8 6}$ & 0.18 & 0.25 & 0.56 & 0.28 & $\mathbf{0 . 8 7}$ \\
\hline
\end{tabular}

Note:The bold values along the diagonal line are the AVE values for the constructs, and the other values are the squared correlations for each pair of constructs; JI $=$ Job involvement; OC $=$ Organizational commitment; PE = Psychological empowerment; JS = Job satisfaction; JP = Job Performance.

\section{Structural Models and Hypotheses Testing}

For the three-star and five-star hotels, standardized path coefficients (ß) and the significance of the hypothesized relationships were utilized to test the proposed hypotheses in a causal diagrammatic form (see figure 2). The data presented in table 5 shows that the findings of the three-star hotels suggest that no significant associate was revealed pertaining to $H 1(B=-0.068, \mathrm{p}>0.05)$ which assumed a positive association between employees' job involvement and employees' job satisfaction. The rest of the hypotheses (i.e., H2, H3, and H4) can be supported since positive association were revealed between employees' commitment and employees' job satisfaction (H2) $(\beta=0.145, \mathrm{p}<0.001)$, employees' psychological empowerment and employees' job satisfaction (H3) $(\beta=0.713, \mathrm{p}<0.001)$, and employees' job satisfaction and employees' job performance $(\beta=0.522, p<0.001)$. In contrast, in the five-star hotels, all hypotheses (i.e., H1, H2, H3, and H4) can be supported since positive association were revealed between employees' job involvement and employees' job satisfaction (H1) $(\beta=0.189, \mathrm{p}<0.001)$, employees' commitment and employees' job satisfaction $(\mathrm{H} 2)(\beta=0.446, \mathrm{p}<0.001)$, employees' psychological empowerment and employees' job satisfaction (H3) $(B=0.218, p<0.001)$, and employees' job satisfaction and employees' job performance $(\beta=0.487, p<0.001)$. 
Table 5: Summary of the structural models for the three-star and five-star hotels

\begin{tabular}{lccccccc}
\hline \multirow{2}{*}{ Hypotheses } & \multirow{2}{*}{ Path } & \multicolumn{3}{c}{ Three-star hotels } & \multicolumn{3}{c}{ Five-star hotels } \\
\cline { 3 - 8 } & & $\beta$ & t-value & Results & $\beta$ & t-value & Results \\
\hline H1 & JI $\rightarrow$ JS & -0.068 & -0.949 & Not supported & 0.189 & $2.191^{*}$ & Supported \\
H2 & OC $\rightarrow$ JS & 0.145 & $2.041^{*}$ & Supported & 0.446 & $5.172^{* *}$ & Supported \\
H3 & PE $\rightarrow$ JS & 0.713 & $5.308^{* *}$ & Supported & 0.218 & $2.203^{*}$ & Supported \\
H4 & JS $\rightarrow$ JP & 0.522 & $5.573^{* *}$ & Supported & 0.487 & $5.518^{* *}$ & Supported \\
\hline
\end{tabular}

$\mathrm{JI}=\mathrm{Job}$ involvement; $\mathrm{OC}=$ Organizational commitment; $\mathrm{PE}=$ Psychological empowerment; JS = Job satisfaction; JP = Job Performance; $\beta=$ Standardized path coefficient; $*$ Absolute t-value $>1.96, \mathrm{p}<$ $0.05 ; * *$ Absolute t-value $>3.29, \mathrm{p}<0.001$.

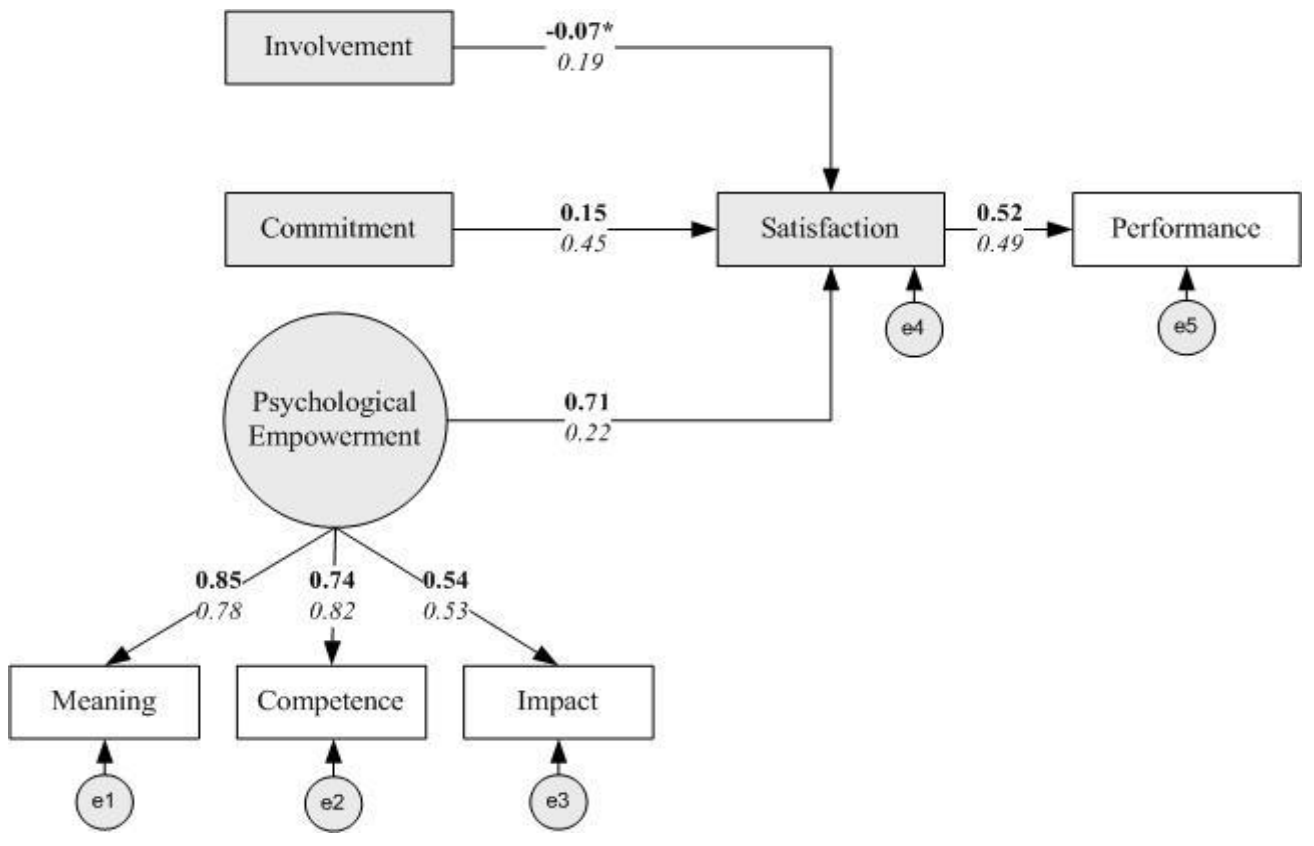

Figure 2:Final structure equation model (Key: bold denotes path coefficients for the three-star hotels; italic denotes path coefficients for the five-star hotels; * denotes non-significant paths) 


\section{Analysis of Variance}

The Mann-Whitney test showed no statistically differenceon the job performance between male and female employees of both three-star $(\mathrm{P}=0.66)$ and five star $(\mathrm{P}=0.36)$ hotels. Therefore, Hypothesis five (H5) was rejected. Similarly, the KruskalWallis test showed no statistically difference on the job performance between younger and elder employees of both three-star $(\mathrm{P}=0.62)$ and five star $(\mathrm{P}=0.19)$ hotels. Hence, Hypothesis six (H6) was rejected. In the same line, the Kruskal-Wallis test showed no statistically difference on the job performance between more experienced and less experienced employees of both three-star $(\mathrm{P}=0.94)$ and five star $(\mathrm{P}=0.31)$ hotels. Therefore, Hypothesis seven $(\mathrm{H} 7)$ was rejected. However, a MannWhitney test showed statistically difference on the job performance between threestar and five-star employees. More specifically, the job performance was significantly greater for employees of five-star hotels $(M=98.84)$ than employees of three-star hotels ( $\mathrm{M}=83.94), \mathrm{U}=3481, \mathrm{P}=0.05$. Therefore, Hypothesis eight (H8) was accepted.

\section{DISCUSSION AND IMPLICATIONS}

The current study revealed that empowerment is a very significant tool in promoting employeejob satisfaction andperformance thus improving overall organizational performance. The current study tested whether empowerment through involvement has any impact on employeejob satisfaction in three-star and five-star hotels in Egypt. In prior studies (e.g., Joo and Park, 2009; Gallardo et al. 2010; Lee and Way, 2010), empowerment through involvement was an important indicator of job satisfaction. Consistent with these studies, the current study revealed that, in five-star hotels, involving employees in the decision making has a positive impact on their job satisfaction. However, involving employees in the decision making in the three-star hotels has no significant impact on their job satisfaction. A possible explanation for these differences is that all investigated three-star hotels were managed independently. In addition, most of these hotels were small hotels (i.e., less than 100 rooms) which employing few numbers ofemployees. Accordingly, most decisions in these hotels are taken by owners. Therefore, managers, especially in three-star hotels, should include the ideas and experiences of their employees in managerial decisionmaking processes. For instance, managers should adopt quality circles that focused on increasing employee involvement and gaining improvements in performance. Team briefing is another way to empower employees via involvement. Team briefing is a mechanism for managers and employees to meet on a regular basis to discuss operational issues. 


\section{Investigatingthe Effects of Employee Empowerment on Job Satisfaction and Performance: A Case Study of Front Office Employees in Egyptian Hotels}

Furthermore, the current study tested whether empowerment through commitment impacts employee job satisfaction. The results showed that empowerment through commitment, in the-three-star and five-star hotels, had significant effect on employee job satisfaction. These findings are consistent with prior research (e.g., Chiang and Jang, 2008; Joo and Park, 2009; Gallardo et al. 2010; Lee and Way, 2010). Nevertheless, empowerment through commitment contributed more to employeejob satisfactionin the five-star hotels $(B=0.45)$ than in the three-star hotels $(B=0.15)$. A possible explanation is that most five-star hotels are employing loyalty programmes in order to retain their employees, compared to three-star hotels. Therefore, hotels, especially three-star hotels, should adopt effective incentive programmes to increase their employees' job satisfaction which in turns increase their loyalty and attachment to the hotel. For example, Developing/designing training programmes that help employees to take the responsibility of authority that will improve their leadership skills and promote their empowerment.

In addition, the current study tested whether psychological empowerment (i.e., empowerment through participation) impacts employee job satisfaction. The results revealed that, in the three-star and five-star hotels, three dimensions of psychological empowerment (i.e.,impact, competence, and meaning) had positive impacts on employee job satisfaction. These findings are consistent with previous studies(e.g., Carless, 2004; Joo and Park, 2009; Gallardo et al. 2010; Lee and Way, 2010). However, psychological climate contributed more to employee job satisfaction in the three-star hotels $(\beta=0.71)$ than in the five-star hotels $(\beta=0.22)$. Possible explanations might be that usually budget hotels are characterized by the family-working environment, as compared to luxury hotels which characterized by the highcompetition working environment. As well, employees working at the budget hotels have opportunity for independence in how they do their jobs, as compared to the luxury hotels where employees are very restricted to the operation standard manual. In order to enforce empowerment through participation, hotels, especially five-star hotels, should empower their employees to have a great deal of control over how to do their jobs. Managers should restructure organizational culture and structure to create empowerment friendly environment. Job enrichment is a good way to enrich employee empowerment through participation. It involves a detailed training programme that encourages front-office employees to understand and empathize with customer experience. Distribution of responsibilities and delegation of power areother good examples for empowering employees through participation. 
Consistent with prior studies (e.g., Kelly, 1992; Sigler and Pearson, 2000), the results of the current study showed that employee job satisfaction had a positive impact on employee job performance. Employees, in the three-star and five-star hotels, who were satisfied with their job empowerment showed higher levels of job performance. Therefore, hotel managers should adopt different forms of empowerment in order to increase their employee job satisfaction which in turns increases their job performance. However, inconsistent with previous research studies (e.g., Tuuli and Rowlinson, 2009; Awamleh, 2013), the results showed no statistically differences on the job performance between male and female employees; younger and elder employees; more experienced and less experienced employees in both hotel categories.

In addition, the current study showed statistically difference on the job performance between the three-star and five-star employees. More specifically, the job performance was significantly greater for employees of the five-star hotels than of the employees of three-star hotels. This is consistent with Rathore and Rathore's (2015) findings. Possible explanations may bethat luxury hotels only are select skilled employees, and provide detailed training programmes to their employees, compared to budget hotels. Accordingly, employees of luxury hotels might show higher levels of performance compared to employees of budget hotels. Therefore, managers of budget hotels should organize and carry out more academic and practical activities to promote the awareness of empowerment concept, importance, and tools of effective application in hotels. As well as managers of budget hotels should re-allocate organizational resources and power (access and utilization) to make fair and balanced empowerment throughout the hierarchy of each department.

\section{LIMITAIONS AND FUTURE RESEARCH}

The study has some limitations; it explained the effects of empowerment on frontoffice employeesatisfaction and performance in Egyptian hotels. In that sense, it is worthwhile to focus on further studies in different departments such as food and beverage department, housekeeping department, and sales and marketing department. Furthermore, this study investigated the empowerment using a sample of three-star and five-star hotels in Greater Cairo, Egypt. Thus, in the further studies, it worthwhile to focus on investigating empowerment in other governorates such as Sharm ElSheikh, Hurghada, or Luxor.In addition, the current study investigated the empowerment from the perspectives of employees only, and it did not go further to explore the empowerment from the perspectives of managers and customers. One of 


\section{Investigatingthe Effects of Employee Empowerment on Job Satisfaction and Performance: A Case Study of Front Office Employees in Egyptian Hotels}

the methodological limitations in this study was the use of self-administrated questionnaires. Future studies using qualitative methods, including interviews, should provide a broader understanding of the empowerment impacts.Furthermore, this study investigated the relationship between the forms of empowerment and job satisfaction and performance ignoring other aspects such as empowering leadership. But despite these limitations, this study has useful implications both for scholars and practitioners.

\section{REFERENCES}

Arbuckle, L. (2011). IBM SPSS Amos 20 User's Guide.Armonk, NY; Amos Development Corporation.

Arnold, A., Arad, S., Rhoades, A., \&Drasgow, F. (2000). The Empowering Leadership Questionnaire: The Construction and Validation of a New Scale for Measuring Leader Behaviours. Journal of Organizational Behaviour, 21(3), pp. 249269.

Awamleh, N. (2013). Enhancing Employees Performance via Empowerment: A Field Study. Asian Journal of Business Management, 5(3), pp. 313-319.

Ayupp, K., \& Chung, H. (2010). Empowerment: Hotel Employees' Perspective. Journal of Industrial Engineering and Management,3(3), pp. 561-575.

Bentler, P., \&Bonett, D. (1980).Significant Tests and Goodness of Fit in the Analysis of Covariance Structures. Psychological Bulletin, 88 (1), pp. 588-606.

Boudrias, J., Gaudreau, P., Savoie, A., \& Morin, A. (2009).Employee Empowerment from Managerial Practices to Employees' Behavioural Empowerment. Leadership \& Organization Development Journal, 30(7), pp. 625-638.

Carless, S. (2004). Does Psychological Empowerment Mediate the Relationship between Psychological Climate and Job Satisfaction? Journal of Business and Psychology, 18(4), pp. 405-425.

Chiang, C.,\& Jang, S. (2008). The Antecedents and Consequences of Psychological Empowerment: The Case of Taiwan's Hotel Companies. Journal of Hospitality \& Tourism Research, 32(1), pp. 40-61. 
Davidson, G., Timo, N., \& Wang, Y. (2010). How Much Does Labour Turnover Cost? A Case Study of Australian Four and Five-Star Hotels.International Journal of Contemporary Hospitality Management, 22(4), pp. 45-466.

Efraty, D.,\&Sirgy, J. (1990).The Effect of Quality of Working Life (QWL) on Employee Behavioural Responses. Social Indicators Research, 22, pp. 31-47.

Egyptian Hotel Association (2013).Retrieved from:http://www.egyptianhotels.org/ Gallardo, E., Sanchez, M., Lopez, T., \& Jesus, N. (2010).Employee Satisfaction in the Iberian Hotel Industry. International Journal of Contemporary Hospitality Management, 22(3), pp. 321-334.

Gazzoli, G., Hancer, M., \& Park, Y. (2010). The Role and Effect of Job Satisfaction and Empowerment on Customers' Perception of Service Quality: A Study in the Restaurant Industry. Journal of Hospitality \& Tourism Research, 34 (1), pp. 56-77.

Hair, J., Black, W., Babin, B., \& Anderson, R. (2010).Multivariate Data Analysis (Seventh Edition). New Jersey: Pearson Prentice Hall.

He, P., Murrmann, S. K. and Perdue, R.(2010) An Investigation of the Relationshipsamong Employee Empowerment, Employee Perceived Service Quality, and Employee Job Satisfaction in a U.S.Hospitality Organization, Journal of Foodservice Business Research, 13 (1), pp. 36-50

Honold, L. (1997). A Review of the Literature on EmployeeEmpowerment. Empowerment in Organizations, 5(4), pp. 202-212.

Joo, K.,\& Park, S. (2009). Career Satisfaction, Organizational Commitment and Turnover Intention. Leadership and Organizational Development Journal, 31(6), pp. 482-500.

Karatepe, M., \&Kilic, H. (2007).Relationships of Supervisor Support and Conflicts in the Work-Family Interface with the Selected Job Outcomes of Frontline Employees. Tourism Management, 28(1), pp. 238-252.

Kelly, J. (1992). Does Job Re-design Theory Explain Job Re-design Outcomes? Human Relations, 45, pp. 753-71.

Lashley, C. (1995). Towards an Understanding of Employee Empowerment in Hospitality Services. International Journal of Contemporary Hospitality Management, 7(1), pp. 27-32. 


\section{Investigatingthe Effects of Employee Empowerment on Job Satisfaction and Performance: A Case Study of Front Office Employees in Egyptian Hotels}

Lashley, C. (1999). Employee Empowerment in Services: A Framework for Analysis. Personnel Review, 28(3), pp. 169-191.

Lashley, C. (2001). Empowerment: Human Resources Strategies for Service Excellence. Woburn, MA.: Reed Elsevier Publishing Group.

Leach, J., Wall, D., \& Jackson, R. (2003). The Effect of Empowerment on Job Knowledge: An Empirical Test Involving Operators of Complex Technology. Journal of Occupational and Organizational Psychology, 76, pp. 27-52.

Lee, C., \& Way, K. (2010).Individual Employment Characteristics of Hotel Employees that Play a Role in Employee Satisfaction and Work Retention. International Journal of Hospitality Management, 29, pp. 344-353.

Logan, M., \&Ganster, D. (2007). The Effects of Empowerment on Attitudes and Performance: The Role of Social Support and Empowerment Beliefs. Journal of Management Studies, 44(8), pp. 1523-1550.

Melhem, Y. (2004). The Antecedents of Customer-Contact Employees' Empowerment. Employee Relations, 26(1), pp. 72-93.

Ng, T., Rose, M., Mak, M., \& Chen, E. (2002). Problematic Issues Associated with Project Partnering: The Contractor Perspective. International Journal of Project Management, 20(6), pp. 437-449.

O'Creevy, M. (2001). Employee Involvement and the Middle Manager: Saboteur or Scapegoat. Human Resource Management Journal, 11(1), pp. 24-40.

Rathore, S., \&Rathore, P. (2015). Talent Management Practices in Luxury and Low Budget Hotels: Conceptual Viewpoint. IRJMST, 6(7), pp. 122-130.

Raub, S.,\& Robert, C. (2012). Empowerment, Organizational Commitment, and Voice Behaviour in the Hospitality Industry: Evidence from a Multiple Sample. Cornell Hospitality Quarterly, 54(2), pp. 136-148.

Robbins, S.,\& Judge, A. (2007). Organizational Behaviour (TwelveEdition). Upper Saddle River, New Jersey: Prentice-Hall.

Seibert, E., Silver, R.,\& Randolph, A. (2004).Taking Empowerment to the Next Level: A Multiple-Level Model of Empowerment, Performance, and Satisfaction. Academy of Management Journal, 47(3), pp. 332-49. 
Shackleton, V. (1995), Business Leadership, Routledge, London. Cited in Green, N., \&Macandrew, J. (1999). Re-empowering the Empowered - the Ultimate Challenge? Personnel Review, 28(3), pp. 258-278.

Sigler, H.,\& Pearson, M. (2000).Creating an Empowering Culture: Examining the Relationship between Organizational Culture and Perceptions of Empowerment. Journal of Quality Management, 5, pp. 27-52.

Smith, J. (1996). Empowering People.Kogan Page, London. Cited in Psoinos, A., Kern, T.,\& Smithson, S. (2000). An Exploratory Study of Information Systems in Support of Employee Empowerment. Journal of Information Technology, 15, pp. 211-230.

Spinelli, A., \&Canavos, C. (2000).Investigating the Relationship between Employees Satisfaction and Guest Satisfaction. Cornell Hotel and Restaurant Administration Quarterly, 41(6), pp. 29-33.

Spreitzer, G. (1995). Psychological Empowerment in the Workplace: Dimensions, Measurement, and Validation. Academy of Management Journal, 38(5), pp. 14421465 .

Spreitzer, G. (2007). Taking Stock: A Review of More Than Twenty Years of Research on Empowerment at Work. Cited in Biron, M.,\& Bamberger, P. (2010). The Impact of Structural Empowerment on Individual Well-being and Performance: Taking Agent Preferences, Self-Efficacy and Operational Constraints into Account. Human Relations, 63(2), pp. 163-191.

Sprietzer, G., Kizilos, M., \&Nason, S. (1997).A dimensional Analysis of the Relationship between Psychological Empowerment and Effectiveness, Satisfaction, and Strain. Journal of Management, 23(5), 679-704.

Steers, M. (1977).Antecedents and Outcomes of Organizational Commitment.Administrative Sciences Quarterly, 22(1), pp.46-56.

Tabachnick, B., \&Fidell, L. (2007).Using Multivariate Statistics (fifth edition). New York: Allyn and Bacon.

Thomas, K., \&Velthouse, B. (1990).Cognitive Elements of Empowerment. Academy of Management Review, 15 (4), pp. 666-681. 
Tuuli, M., \&Rowlinson, S. (2009).Performance Consequences of Psychological Empowerment. Journal Construction Engineering and Management, 135(12), pp. 1334-1347.

Wilkinson, A. (1998). Empowerment: Theory and Practice. Personnel Review, 27(1), pp. $40-56$.

Zopiatis, A., Constanti, P., \& Theocharous, A. (2014). Job Involvement, Commitment, Satisfaction and Turnover: Evidence from Hotel Employees in Cyprus. Tourism Management, 41, pp. 129-140. 